\title{
Isolasi dan Uji Aktivitas Kitosan Cangkang Kerang Bulu (Anadara inflata) sebagai Antibakteri terhadap Staphylococcus epidermidis dan Escherichia coli
}

\author{
Suherman Baharuddin dan Dewi Isnaeni \\ Fakultas Farmasi, Universitas Indonesia Timur, Makassar, Indonesia \\ Korespondensi: Suherman Baharuddin \\ Email: ince.suherman81@gmail.com
}

Submitted : 23-10-2020, Revised : 26-11-2020, Accepted : 17-12-2020

\begin{abstract}
ABSTRAK: Kitosan merupakan modifikasi kitin yang berpotensi untuk dikembangkan sebagai kandidat antimikroba karena mengandung enzim lisozim dan gugus aminopolisakarida yang dapat menghambat pertumbuhan mikroba. Tujuan dari penelitian ini untuk mengetahui karakteristik isolat kitosan dari cangkang kerang bulu (Anadara inflata) dan untuk menentukan aktivitas antibakterinya terhadap Staphylococcus epidermidis dan Escherichia coli hasil isolat kultur pus. Metode isolasi yang digunakan meliputi deproteinasi, demineralisasi, depigmentasi, dan deasetilasi 3 tahap. Uji aktivitas antibakteri dilakukan dengan metode difusi cakram (Tes Kirby-Bauer). Hasil penelitian menunjukkan rendemen isolat sebanyak 81,06\%, berbentuk serpihan serbuk, berwarna putih keabu-abuan dan tidak berbau. Uji kelarutan menunjukkan kitosan larut dalam asam asetat. Kadar air dan kadar abu yang didapatkan masing-masing sebesar 4,70 dan 1,17\%, serta dari pengujian dengan pelarut ninhidrin didapatkan perubahan warna dari kuning menjadi ungu setelah didiamkan. Aktivitas antibakteri kitosan terhadap S. epidermidis dan E. coli pada masa inkubasi 1 x 24 jam dan 2 x 24 jam menunjukkan bahwa semakin tinggi konsentrasi kitosan, maka semakin besar pula zona hambat (aktivitas) yang dihasilkan. Konsentrasi yang paling aktif yaitu pada 7\% b/v (oneway ANOVA, $\alpha=0,05$ ).
\end{abstract}

Kata kunci: Anadara inflata; antibakteri; kitosan; Staphylococcus epidermidis; Escherichia coli

\begin{abstract}
Chitosan is a modified chitin compound that has the potential to be developed as an antimicrobial candidate, because it contains lysozyme enzymes and aminopolysaccharide groups that can inhibit microbial growth. The purpose of this study was to determine the characteristics of chitosan isolated from mussel shells (Anadara inflata) and to determine their antibacterial activity against Staphylococcus epidermidis and Escherichia coli from pus culture isolates. The isolation method used included deproteination, demineralization, depigmentation, and 3-stage deacetylation as well as testing for antibacterial activity using the disc diffusion method (Kirby-Bauer test). The results showed that the yield was 81.06\%, in the form of powder flakes, grayish white and odorless. The solubility test showed that chitosan was soluble in acetic acid. The water content and ash content obtained were $4.70 \%$ and $1.17 \%$ respectively, and from testing with the ninhydrin solvent, the color change was from yellow to purple after being left idle. The antibacterial activity of mussel shell chitosan against $S$. epidermidis and E. coli from pus culture isolates during the incubation period of $1 \times 24$ hours and $2 \times 24$ hours shows that the higher the concentration of mussel shell chitosan, the greater the inhibition zone (activity). The most active concentration is at a concentration of $7 \%$ $w / v$. Antibacterial activity data were statistically analyzed using the oneway ANOVA test method ( $\alpha=0.05)$.
\end{abstract}

Keywords: Anadara inflata; antibacterial; chitosan; Staphylococcus epidermidis; Escherichia coli 


\section{Pendahuluan}

Wilayah laut Indonesia memiliki zona yang dikenal sebagai Zona Ekonomi Eksklusif Indonesia (ZEEI). Di dalam zona tersebut, potensi kekayaan lautnya, seperti ikan diperkirakan mencapai 6,4 juta ton per tahun. Salah satu kekayaan laut Indonesia yang lainnya adalah kerang bulu (Anadara inflata). Daging yang terdapat pada kerang memiliki kandungan protein yang sangat bagus untuk kesehatan bila dikonsumsi, namun cangkang kerang yang membungkus daging tersebut seringkali tidak dimanfaatkan dan dibuang begitu saja, sehingga menyebabkan terjadinya limbah cangkang kerang [1].

Dewasa ini limbah menjadi masalah yang harus segera ditangani karena memiliki efek yang sangat serius terhadap mahluk hidup, salah satunya adalah pencemaran lingkungan yang dapat menimbulkan berbagai macam penyakit. Limbah juga cenderung mengandung bahan kimia beracun dan berbahaya bagi kesehatan [2]. Potensi hasil kerang bulu yang besar akan berdampak pada peningkatan limbah cangkang kerang yang dihasilkan, baik limbah cair maupun padat. Jika limbah-limbah ini dibiarkan terus menumpuk tanpa adanya penanganan khusus maka akan menimbulkan pencemaran dan estetika lingkungan terganggu. Kerang merupakan Mollusca yang mengandung kitin, sehingga limbah padatnya yang berupa cangkang berpotensi untuk diolah dan dikembangkan menjadi sesuatu yang bernilai ekonomis lebih tinggi. Sifat kitin yang tidak beracun dan mudah terdegradasi mendorong dilakukannya berbagai upaya modifikasi kitin dengan tujuan mengoptimalkan kegunaan maupun memperluas penggunaan kitin di berbagai bidang. Salah satu senyawa turunan dari kitin yang banyak dikembangkan karena aplikasinya yang luas adalah kitosan $[1,3]$.

Kitosan sangat berpotensi untuk dijadikan sebagai antimikroba karena mengandung enzim lisozim dan gugus aminopolisakarida yang dapat menghambat pertumbuhan mikroba. Enzim lisozim merupakan enzim yang memiliki kemampuan dalam mencerna dinding sel bakteri sehingga bakteri akan kehilangan kemampuannya menimbulkan penyakit dalam tubuh. Hilangnya dinding sel ini menyebabkan sel bekteri akan mati. Kemampuan dalam menekan pertumbuhan bakteri disebabkan kitosan memiliki polikation bermuatan positif yang mampu menghambat pertumbuhan bakteri [4].

Infeksi piogenik merupakan infeksi yang ditandai dengan terjadinya peradangan lokal yang parah dan biasanya dengan pembentukan nanah (pus). Infeksi piogenik dapat disebabkan karena adanya invasi dan multiplikasi mikroorganisme patogen di jaringan sehingga mengakibatkan luka pada jaringan dan berlanjut menjadi penyakit, melalui berbagai mekanisme seluler dan umumnya disebabkan oleh salah satu kuman piogenik [5]. Komplikasi yang timbul dari infeksi kulit dan jaringan lunak karena Staphylococcus aureus merupakan masalah klinis yang utama. Hal ini dikarenakan tingginya kejadian infeksi dan munculnya strain kuman resisten antibiotik secara luas. Oleh karena itu, kuman yang menghasilkan leukosidin disebut sebagai kuman piogenik [6]. Leukosidin adalah toksin yang dihasilkan oleh Staphylococcus yang secara spesifik ditujukan untuk menghalang kerja polimorfonuklear leukosit dan dapat dikatakan sebagai salah satu faktor virulensi. Beberapa faktor virulensi pada Staphylococcus antara lain tipe antigen permukaan, enzim degradasi, enterotoksin, hemolisin, dan termasuk leukosidin [7].

Berdasarkan uraian di atas, perlu dilakukan penelitian isolasi dan uji aktivitas kitosan cangkang kerang bulu sebagai antibakteri terhadap Staphylococcus epidermidis dan Escherichia coli dengan tujuan untuk mengetahui karakteristik serta sejauh mana aktivitas antibakterinya.

\section{Metode}

\subsection{Rancangan penelitian}

Penelitian ini merupakan penelitian 
eksperimental yang dilakukan dengan metode isolasi dan uji aktivitas kitosan cangkang kerang bulu sebagai antibakteri terhadap S. epidermidis dan E. coli hasil isolat kultur pus. Pengambilan sampel dilakukan di Kelurahan Bonto Sunggu, Kecamatan Bissappu, Kabupaten Bantaeng, Sulawesi Selatan. Pengolahan dan proses deproteinasi, demineralisasi, depigmentasi, dan deasetilasi, serta karakterisasi dilakukan di Laboratorium Kimia Farmasi Universitas Indonesia Timur Makassar. Pengambilan dan isolasi bakteri hasil isolat kultur pus dilakukan di Laboratorium Mikrobiologi Rumah Sakit Ibnu Sina Makassar. Pengujian aktivitas antibakteri dilakukan di Laboratorium Mikrobiologi Farmasi Universitas Indonesia Timur.

\subsection{Pengolahan bahan uji}

Kerang bulu yang didapat dari daerah Kabupaten Bantaeng selanjutnya diambil cangkangnya, kemudian cangkang dicuci dengan air dan dikeringkan di bawah sinar matahari. Selanjutnya bahan yang sudah kering ditumbuk dan diblender sampai menjadi serbuk dan diayak menggunakan ayakan 100 mesh. Setelah itu dilakukan tahap deproteinasi, demineralisasi, depigmentasi, dan deasetilasi 3 tahap [8].

\subsection{Isolasi kitosan}

Isolasi kitosan cangkang kerang bulu mengacu pada Bahri et al. yang mencakup proses deproteinasi, demineralisasi, depigmentasi, dan deasetilasi 3 tahap [9]. Deproteinasi dilakukan untuk menghilangkan protein dari serbuk cangkang kerang bulu. Proses ini dilakukan pada suhu $60-80^{\circ} \mathrm{C}$ menggunakan $\mathrm{NaOH} 1 \mathrm{M}$ dengan perbandingan serbuk cangkang kerang bulu dengan $\mathrm{NaOH}=70: 700$ (gram serbuk/ml NaOH), selama 1 jam. Demineralisasi yaitu penghilangan mineral dari hasil deproteinasi pada suhu $60-80^{\circ} \mathrm{C}$ menggunakan $\mathrm{HCl} 1 \mathrm{M}$ (dengan ratio 70:700 b/v), selama 3 jam. Pada proses depigmentasi, endapan hasil demineralisasi ditambahkan ase- ton kemudian di-bleaching (pemutihan) dengan 0,315\% NaOCl selama 1 jam pada suhu kamar. Proses terakhir adalah deasetilasi, dimana kitin yang telah dihasilkan pada proses depigmentasi dimasukkan ke dalam $\mathrm{NaOH} 60 \%$ pada suhu 90$100^{\circ} \mathrm{C}$ sambil diaduk dengan kecepatan konstan selama 60 menit. Deasetilasi dilakukan sampai 3 kali pengulangan dengan variasi waktu reaksi 1 x 3, 2 x 3, dan 3 x 3 jam. Hasil yang didapatkan yaitu berupa slurry yang dilanjutkan dengan penyaringan, endapan dicuci dengan aquadest lalu ditambah $\mathrm{HCl}$ encer agar $\mathrm{pH}$ netral kemudian dikeringkan dalam oven selama 24 jam. Hasil yang diperoleh merupakan senyawa kitosan.

\subsection{Karakterisasi kitosan}

Karakterisasi kitosan meliputi penentuan kadar air, kadar abu, kelarutan, dan uji ninhidrin [1] .

\subsection{Pengujian aktivitas antibakteri terhadap $S$. epidermidis dan E. coli}

Konsentrasi kitosan yang digunakan pada pengujian aktivitas antibakteri adalah 1, 3, 5, dan $7 \%$. Konsentrasi $1 \%$ dibuat dengan cara serbuk kitosan ditimbang sebanyak 1 gram, kemudian dimasukkan ke dalam labu ukur $100 \mathrm{ml}$, setelah itu ditambahkan dengan larutan asam asetat $1 \%$ sedikit demi sedikit hingga kitosan larut kemudian dicukupkan volumenya sampai tanda batas. Cara yang sama dilakukan untuk pembuatan konsentrasi kitosan 3, 5, dan 7\% yaitu dengan menimbang serbuk kitosan masing-masing sebanyak 3, 5, dan $7 \mathrm{~g}$, selanjutnya dimasukkan ke dalam labu ukur $100 \mathrm{ml}$, ditambahkan larutan asam asetat $1 \%$ sedikit demi sedikit hingga kitosan larut kemudian dicukupkan volumenya sampai tanda batas [10].

Media Mueller Hinton Agar dituang secara aseptis dan dimasukkan ke dalam masing-masing cawan petri steril sebanyak $20 \mathrm{ml}$ lalu ditambahkan $1 \mathrm{ml}$ suspensi $S$. epidermidis atau E. coli, kemudian dihomogenkan dan dibiarkan memadat. Setelah memadat, diletakkan kertas cakram yang 
sebelumnya telah direndam dalam larutan kitosan cangkang kerang bulu konsentrasi 1, 3, 5, dan $7 \%$ dan kontrol negatif asam asetat $1 \% \mathrm{v} / \mathrm{v}$. Pengaturan jarak kertas cakram dari pinggir cawan petri minimal $20 \mathrm{~mm}$ kemudian diinkubasi pada suhu $37^{\circ} \mathrm{C}$ selama 1 x 24 jam dan 2 x 24 jam. Daerah hambatan yang terbentuk diukur dengan mistar geser. Perlakuan ini direplikasi 3 kali, dihitung rata-rata dan deviasi standarnya [10].

\subsection{Analisis data}

Hasil pengukuran diameter hambatan pertumbuhan bakteri dianalisis dengan metode analisis varian (oneway ANOVA) dan uji korelasi menggunakan bantuan program IBM SPSS Statistics versi 26.

\section{Hasil dan pembahasan}

\subsection{Isolasi kitosan cangkang kerang bulu}

Kitosan dan turunannya memiliki manfaat yang sangat besar dalam berbagai bidang, yaitu bidang pangan, pertanian, farmasi, dan dapat juga diaplikasikan pada bidang mikrobiologi karena kitosan memiliki banyak keunggulan, diantaranya memiliki struktur yang mirip dengan serat selulosa dan mampu menghambat serta membunuh mikroba atau sebagai zat antibakteri [11]. Kitosan merupakan modifikasi senyawa kitin yang banyak terdapat dalam kulit luar hewan golongan Crustaceae [12]. Kitosan merupakan biopolimer yang bersifat hidrofilik yang diperoleh dari proses diasetilasi kitin [13, 14]. Selain itu keunggulan lain kitosan diantaranya adalah merupakan bahan alami, dapat digunakan dalam jumlah sedikit (konsentrat), memiliki muatan positif yang kuat yang dapat mengikat muatan negatif dari senyawa lain sehingga dapat berperan dalam detoksifikasi dan penghambatan pertumbuhan bakteri, serta mudah mengalami degradasi secara biologis dan tidak beracun [15]. Sarwono menyatakan bahwa kitosan banyak kegunaannya dalam pemakaian seharihari, seperti pengawet makanan yang aman, antioksidan, penyerap lemak, antimikroba, dan dalam bidang kedokteran dibuat sebagai benang operasi [15].

Untuk mendapatkan senyawa kitosan dari cangkang kerang bulu, dilakukan isolasi dengan urutan tahapan deproteinasi, demineralisasi, depigmentasi, dan deasetilasi 3 tahap. Pada proses deproteinasi berat awal sampel cangkang kerang bulu sebesar 473,5 g, setelah dikeringkan pada suhu $60^{\circ} \mathrm{C}$ selama 24 jam dan didinginkan dalam eksikator didapatkan berat akhir sebesar 419,5 g. Pada proses demineralisasi berat awal sampel 419,5 g yang merupakan berat dari hasil deproteinasi kemudian setelah dikeringkan selama 24 jam didapatkan berat akhir dari proses tersebut sebesar 72,2 g. Pada proses depigmentasi dengan berat awal 72,2 g yang merupakan berat dari hasil demineralisasi, didapatkan berat akhir setelah pengeringan sebesar 72,18 g dan pada tahap ini menghasilkan kitin. Proses akhir yaitu deasetilasi 3 tahap dengan berat awal sampel sebesar 71,3 g dan setelah dikeringkan selama 24 jam didapatkan berat akhir sebesar 57,8 g (senyawa kitosan). Hasil isolasi kitosan cangkang kerang bulu dapat dilihat pada Tabel 1 .

Sulistyoningrum menyatakan bahwa kitosan yang diperoleh dari berbagai sumber memiliki struktur yang sama yaitu $\left(\mathrm{C}_{6} \mathrm{H}_{11} \mathrm{NO}_{4}\right) \mathrm{n}$, karena sampel mengalami proses yang sama yaitu demineralisasi, deproteinasi, dan deasetilasi,

Tabel 1. Hasil isolasi kitosan cangkang kerang bulu

\begin{tabular}{lllll}
\hline No & Tahapan & Berat sampel awal $(\mathbf{g})$ & Berat akhir $(\mathbf{g})$ & Keterangan \\
\hline 1. & Deproteinasi & 473,5 & 419,5 & Uji lanjut tahap 2 \\
2. & Demineralisasi & 419,5 & 72,2 & Uji lanjut tahap 3 \\
3. & Depigmentasi & 72,2 & 72,18 & Kitin uji lanjut tahap 3 \\
4. & Deasetilasi 3 tahap & 71,3 & 57,8 & Kitosan \\
\hline
\end{tabular}


Tabel 2. Hasil karakterisasi kitosan cangkang kerang bulu

\begin{tabular}{lll}
\hline No & Spesifikasi & Deskripsi \\
\hline 1 & Rendemen (\%) & 81,06 \\
2 & Bentuk & Serpihan serbuk \\
3 & Warna & Putih abu-abu \\
4 & Bau & Tidak berbau \\
5 & Kadar air (\%) & 4,70 \\
6 & Kadar abu (\%) & 1,17 \\
\hline 7 & Uji ninhidrin & Berubah warna dari kuning menjadi ungu \\
\hline
\end{tabular}

Tabel 3. Hasil uji kelarutan kitosan cangkang kerang bulu

\begin{tabular}{|c|c|c|}
\hline No & Pelarut & Hasil \\
\hline 1 & Aquadest & Tidak larut \\
\hline 2 & Alkohol & Tidak larut \\
\hline 3 & HCl pekat & Sedikit larut \\
\hline 4 & $\mathrm{NaOH}$ encer & Tidak larut \\
\hline 5 & Asam asetat & Larut \\
\hline 6 & Kloroform & Tidak larut \\
\hline 7 & $\mathrm{H}_{2} \mathrm{SO}_{4}$ pekat & Sedikit larut \\
\hline 8 & Asam nitrat & Tidak larut \\
\hline 9 & $\mathrm{HCl}$ encer & Sedikit larut \\
\hline 10 & $\mathrm{H}_{2} \mathrm{SO}_{4}$ encer & Tidak larut \\
\hline
\end{tabular}

sehingga senyawa lain yang menyusun sampel dapat dipisahkan sehingga terbentuk senyawa murni yang berupa kitosan [16].

\subsection{Karakterisasi kitosan}

Hasil karakterisasi terhadap kitosan cangkang kerang bulu menunjukkan rendemen sebesar 81,06\%, berbentuk serpihan serbuk, berwarna putih keabu-abuan, dan tidak berbau. Kadar air kitosan sebesar 4,70\%, kadar abu sebesar 1,17\%, dan melalui uji ninhidrin didapatkan perubahan warna dari kuning menjadi ungu setelah didiamkan. Kadar air yang didapatkan sesuai dengan standar mutu yang telah ditetapkan. Apsari serta Hastuti dan Nurina mengemukakan bahwa standar kadar air kitosan sebesar 2-10\%. Kadar air pada kitosan kemungkinan besar sangat dipengaruhi oleh jumlah kitosan yang dikeringkan, luas tempat kitosan dikeringkan serta lama pengeringan. Kadar air yang tinggi juga akan menyebabkan senyawa kitosan cepat mengalami kerusakan sehingga memungkinkan ditumbuhi oleh mikroorganisme seperti jamur
$[1,17]$.

Kadar abu yang didapatkan dari kitosan cangkang kerang bulu berada di atas standar yang telah ditetapkan yakni untuk kualitas kitosan yang baik memiliki kadar abu $<1 \%$. Ini dimungkinkan pada saat proses demineralisasi, mineral-mineral yang terkandung dalam sampel belum sepenuhnya hilang. Kadar abu adalah indikator efektivitas tahap demineralisasi untuk menghilangkan mineral yang ada pada kitosan [1]. Dampak dengan masih adanya kandungan mineral pada kitosan memungkinkan kualitas serta tingkat kemurnian dari kitosan yang dihasilkan semakin rendah. Keberadaan mineral dan oksida lainnya pada kitosan serta tingginya kadar abu menyebabkan hasil yang didapatkan dari pengujian aktivitas antibakteri dari kitosan belum optimal.

Uji ninhidrin kitosan hasil isolasi menunjukkan positif yang dapat dilihat dari perubahan warna ungu yang terjadi setelah kitosan diinteraksikan dengan larutan ninhidrin. Ninhidrin merupakan oksidator kuat yang bereaksi dengan gugus 
Tabel 4. Hasil pengujian aktivitas kitosan cangkang kerang bulu terhadap S. epidermidis masa inkubasi $1 \times 24$ dan $2 \times 24$ jam

\begin{tabular}{llllll}
\hline Masa inkubasi & \multicolumn{5}{l}{ Diameter zona hambatan $(\mathbf{m m})$} \\
\cline { 2 - 6 } & Kontrol (-) & $\mathbf{1 \%}$ & $\mathbf{3 \%}$ & $\mathbf{5 \%}$ & $\mathbf{7 \%}$ \\
\hline $1 \times 24$ jam & $6,36 \pm 0,12$ & $7,73 \pm 0,15$ & $8,83 \pm 0,15$ & $10,90 \pm 0,69$ & $12,03 \pm 0,49$ \\
$2 \times 24$ jam & $6,46 \pm 0,21$ & $7,53 \pm 0,06$ & $8,60 \pm 0,20$ & $11,86 \pm 0,47$ & $12,56 \pm 0,40$ \\
\hline
\end{tabular}
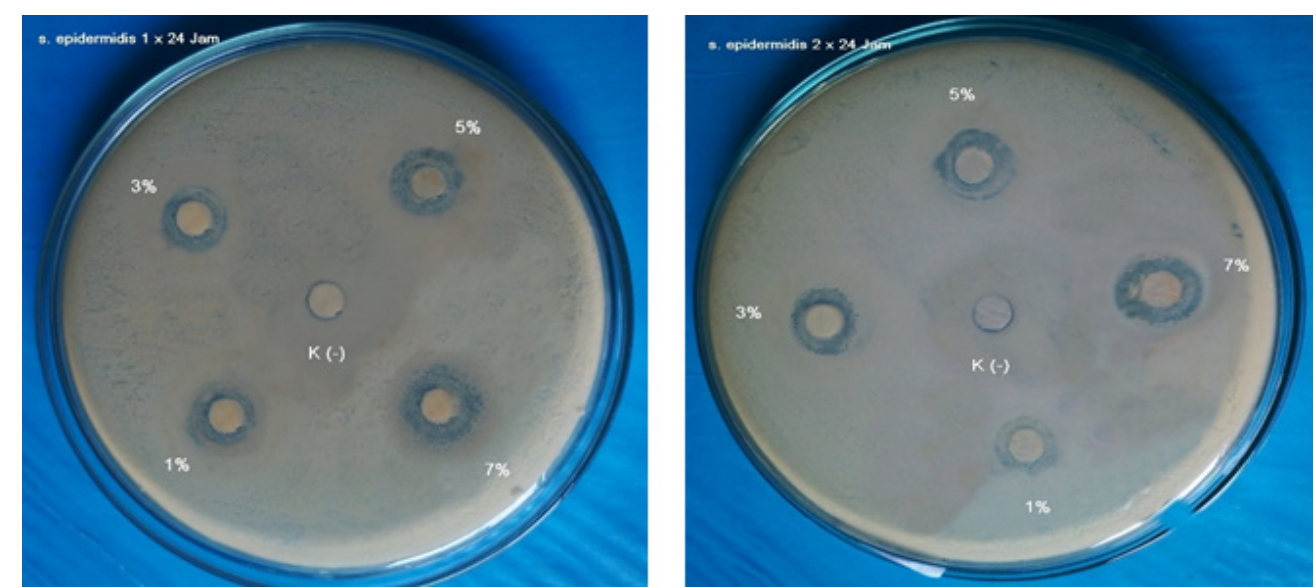

Gambar 1. Diameter zona hambat kitosan cangkang kerang bulu terhadap pertumbuhan S. epidermidis dengan masa inkubasi 1 × 24 dan 2 × 24 jam

K (-): kontrol negatif; $1 \%, 3 \%, 5 \%$, dan 7\% masing-masing adalah kitosan konsentrasi 1\%, $3 \%, 5 \%$, dan $7 \%$ b/v

amina dari senyawa kitosan pada $\mathrm{pH}$ 4-8 dan menghasilkan senyawa hasil ikatan antara hidrinedantin dan ninhidrin melalui jembatan nitrogen yang berwarna ungu [8].

Uji kelarutan menunjukkan bahwa kitosan cangkang kerang bulu larut dalam asam asetat $\left(\mathrm{CH}_{3} \mathrm{COOH}\right)$, sedikit larut dalam $\mathrm{HCl}$ pekat, $\mathrm{H}_{2} \mathrm{SO}_{4}$ pekat, dan $\mathrm{HCl}$ encer, serta tidak larut dalam aquadest, alkohol, $\mathrm{NaOH}$ encer, kloroform, asam nitrat, dan $\mathrm{H}_{2} \mathrm{SO}_{4}$ encer. Sugita menyatakan bahwa kitosan merupakan padatan amorf yang berwarna putih kekuningan. Kelarutan kitosan yang paling baik ialah dalam asam asetat 2\% [18]. Hasil karakterisasi kitosan cangkang kerang bulu dapat dilihat pada Tabel 2 dan Tabel 3.

\subsection{Aktivitas antibakteri kitosan}

Pengujian aktivitas antibakteri kitosan cangkang kerang bulu dilakukan terhadap S. epidermidis dan E. coli hasil isolat kultur pus. Kedua bakteri tersebut diisolasi dari sekret luka yang telah mengalami infeksi dan bernanah (pus) yang kemudian dikultur lalu diidentifikasi lebih lanjut melalui pewarnaan gram dan uji biokimia. Kedua bakteri tersebut juga telah melewati uji kepekaan terhadap antibiotika. Hasil pengujian aktivitas antibakteri kitosan cangkang kerang bulu terhadap pertumbuhan S. epidermidis dapat dilihat pada Tabel 4 dan Gambar 1.

Hasil pengujian antara masa inkubasi 1 x 24 jam dan $2 \times 24$ jam jelas terlihat adanya penurunan daya hambat yang terjadi pada konsentrasi 1, 3, dan 5\%, sedangkan pada konsentrasi $7 \%$ mengalami peningkatan. Hal ini kemungkinan disebabkan kitosan cangkang kerang bulu pada konsentrasi kecil hanya bersifat bakteriostatik sebagaimana yang terlihat pada Gambar 2 .

Hasil analisis data dengan menggunakan metode analisis varian (oneway ANOVA) diperoleh nilai Sig. $0.000(<0,05)$, baik pada masa inkubasi $1 \times 24$ jam maupun $2 \times 24$ jam, yang artinya terdapat perbedaan yang bermakna antara variasi konsentrasi dan zona hambat yang dihasilkan. Hal ini dapat dilihat pada data yang diuji, semakin tinggi konsentrasi kitosan maka semakin besar pula zona hambat yang dihasilkan 


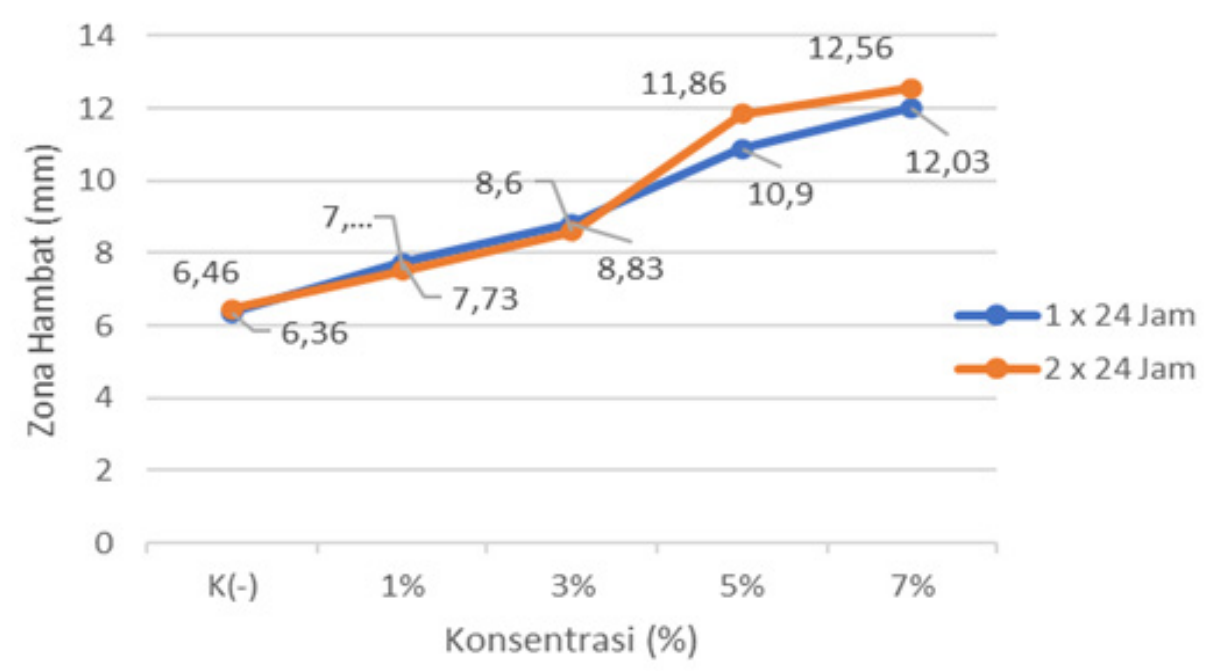

Gambar 2. Hubungan antara konsentrasi kitosan cangkang kerang bulu dengan zona hambat yang di hasilkan terhadap S. epidermidis

Tabel 5. Hasil pengujian aktivitas kitosan cangkang kerang bulu terhadap E. coli masa inkubasi 1 x 24 dan $2 \times 24$ jam

\begin{tabular}{llllll}
\hline Masa inkubasi & \multicolumn{5}{l}{ Diameter zona hambatan $(\mathbf{m m})$} \\
\cline { 2 - 6 } & Kontrol (-) & $\mathbf{1 \%}$ & $\mathbf{3 \%}$ & $\mathbf{5 \%}$ & $\mathbf{7 \%}$ \\
\hline 1 x 24 jam & $6,26 \pm 0,06$ & $7,20 \pm 0,17$ & $8,06 \pm 0,47$ & $9,60 \pm 0,80$ & $11,26 \pm 0,70$ \\
$2 \times 24$ jam & $6,30 \pm 0,00$ & $7,20 \pm 0,17$ & $7,86 \pm 0,29$ & $9,36 \pm 0,65$ & $10,96 \pm 0,67$ \\
\hline
\end{tabular}

pada bakteri uji S. epidermidis.

Hasil pengujian aktivitas antibakteri kitosan cangkang kerang bulu terhadap pertumbuhan $E$. coli dapat dilihat pada Tabel 5 dan Gambar 3. Hasil pengujian pada masa inkubasi $2 \times 24$ jam, jelas terlihat adanya penurunan daya hambat untuk konsentrasi 3, 5, dan 7\%, sedangkan pada konsentrasi $1 \%$ tetap konstan. Hal ini diduga bahwa kitosan cangkang kerang bulu hanya efektif dalam menghambat pertumbuhan E. coli (bakteriostatik), sebagaimana yang terlihat pada Gambar 4.

Hasil analisis data dengan menggunakan metode analisis varian (oneway ANOVA) diperoleh nilai Sig. $0.000(<0,05)$, baik pada masa inkubasi 1 x 24 jam maupun 2 x 24 jam, yang artinya terdapat perbedaan yang bermakna antara variasi konsentrasi dan zona hambat yang dihasilkan. Hal ini dapat dilihat pada data yang diuji, semakin tinggi konsentrasi kitosan cangkang kerang bulu maka semakin besar pula zona hambat yang dihasilkan pada bakteri uji E. coli.
Hasil yang didapatkan dari penelitian ini mengenai aktivitas kitosan dari cangkang kerang bulu baik pada penghambatan terhadap S. epidermidis maupun E. coli sangat berbeda dengan hasil penelitian sebelumnya, dimana dalam penelitian tersebut digunakan kitosan dari kulit udang Vannemei (Litopenaeus vannamei), memiliki penghambatan yang lebih besar terhadap $S$. epidermis ataupun terhadap E. coli [10]. Hal ini kemungkinan disebabkan oleh struktur cangkang dari Anadara inflata ini bertekstur keras dan memiliki 98\% lapisan karbonat CaC (Crystalline calcium Carbonate) sehingga saat isolasi pada tahap demineralisasi belum semuanya tertarik keluar dan kitosan yang dihasilkan belum sepenuhnya terbebas dari kandungan mineral di dalamnya. Akhirnya ketika pada saat pengujian, gugus fungsional amina $\left(-\mathrm{NH}_{2}\right)$ yang bermuatan positif pada kitosan Anadara inflata ini kurang kuat dalam menarik molekul asam amino yang bermuatan negatif pembentuk protein dalam bakteri. 

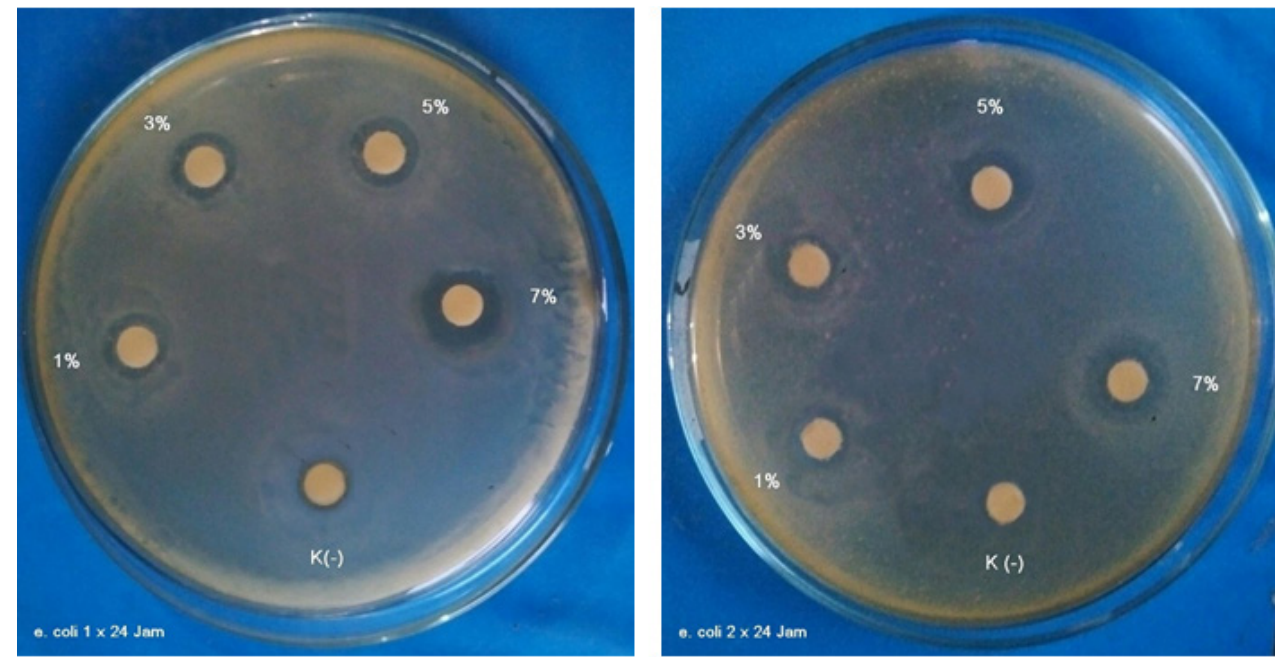

Gambar 3. Diameter zona hambat kitosan cangkang kerang bulu (terhadap pertumbuhan E. coli dengan masa inkubasi 1 × 24 dan 2 × 24 jam

$\mathrm{K}(-)$ : kontrol negatif; $1 \%, 3 \%, 5 \%$, dan 7\% masing-masing adalah kitosan konsentrasi 1\%, $3 \%, 5 \%$, dan $7 \% \mathrm{~b} / \mathrm{v}$

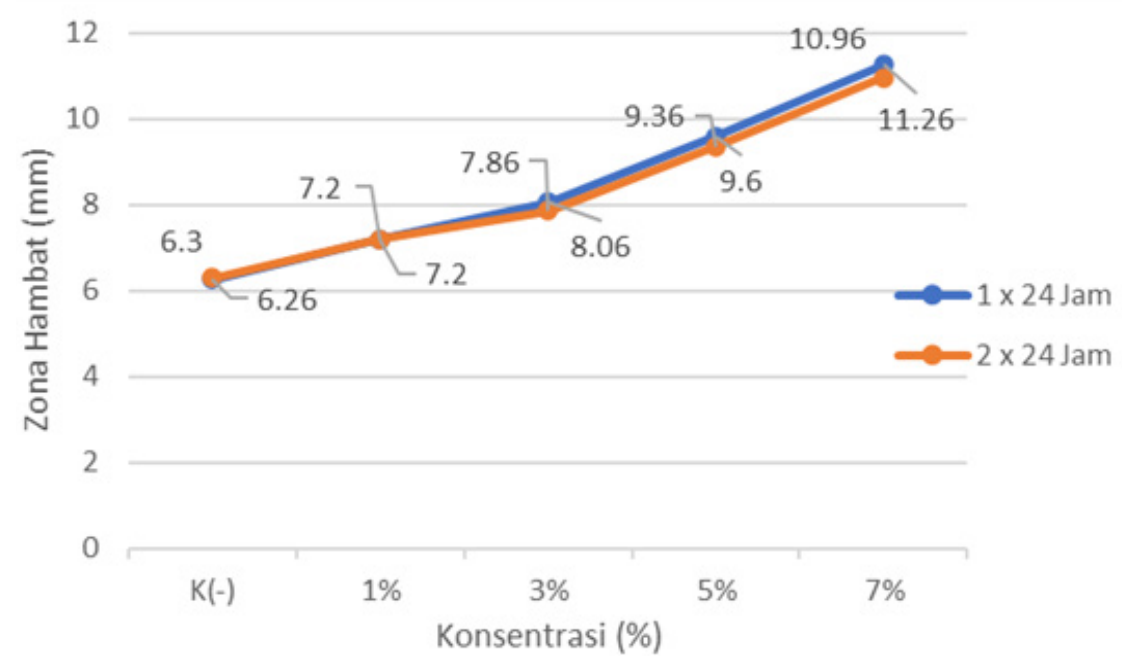

Gambar 4. Hubungan antara konsentrasi kitosan cangkang kerang bulu dengan zona hambat yang dihasilkan terhadap E. coli

Adanya penghambatan yang terjadi terhadap kontrol negatif dalam penelitian ini karena asam asetat $1 \%$ selain sebagai pelarut adsorben dari kitosan juga asam asetat memiliki gugus-gugus yang berikatan satu sama lain serta memiliki ion $\mathrm{H}$ - yang nantinya ikut berinteraksi dengan gugus amina $\left(-\mathrm{NH}_{2}\right)$ pada kitosan dalam menghambat pertumbuhan mikroorganisme dan juga asam asetat sebagai pelarut kitosan mampu memprotonasi gugus amina menjadi amino kationik $\left(-\mathrm{NH}_{3}+\right)$ serta kitosan yang larut dalam asam asetat akan membentuk campuran homogen ken- tal. Interaksi bahan antimikroorganisme dapat melalui interaksi ionik dan interaksi hidrofobik, namun karena kitosan tidak memiliki gugus alkil hidrofobik maka kemungkinan besar interaksi sifat antimikroorganisme polimer kitosan dengan bakteri melalui interaksi ionik antara polikationik ammonium kuarterner kitosan dengan muatan ion negatif sel mikroorganisme seperti interaksi dengan menggunakan asam asetat. Menurut Liu et al., asam asetat dengan konsentrasi 0,5-1\% memiliki aktivitas antibakteri, oleh karena itu ketika digunakan sebagai pelarut kitosan maka pe- 
ran serta asam asetat tidak dapat diabaikan [19]. Salah satu asam organik seperti asam asetat telah digunakan secara luas sebagai aditif antibakteri. Asam terdisosiasi menjadi ion hidrogen dan anion toksik yang mampu mengganggu fungsi fisiologis sel dan mendestabilasi protein sel [20]. Selain itu, asam terdisosiasi yang menembus membran akan menjadi penyebab kematian sel [21].

\section{Kesimpulan}

Kitosan dapat diisolasi dari cangkang kerang bulu (Anadara inflata) melalui tahap deproteinasi, demineralisasi, depigmentasi, dan deasetilasi 3 tahap dengan rendemen sebesar 81,06\%. Kitosan yang didapatkan berbentuk serpihan serbuk, berwarna putih keabu-abuan, tidak berbau, larut dalam asam asetat, dengan kadar air sebesar 4,70\% dan kadar abu 1,17\%. Pengujian dengan ninhidrin didapatkan perubahan warna dari kuning menjadi ungu setelah didiamkan. Kitosan cangkang kerang bulu memiliki aktivitas antibakteri terhadap Staphylococcus epidermidis dan Escherichia coli hasil isolat kultur pus pada masa inkubasi 1 x 24 jam dan 2 × 24 jam, dimana semakin tinggi konsentrasi kitosan semakin besar pula zona hambat (aktivitas) yang dihasilkan.

\section{Ucapan Terima Kasih}

Ucapan terima kasih disampaikan kepada Lembaga Penelitian dan Pengabdian Masyarakat (LPPM) Universitas Indonesia Timur Makassar atas pendanaan penelitian ini dalam skema Penelitian Dosen Pemula (PDP) 2020 dengan nomor kontrak penelitian 202/ UIT.2.00/F0.PJ/VIII/2020 dan Kepala Lembaga Layanan Pendidikan Tinggi Wilayah IX dengan amandemen kontrak penelitian nomor: 4376/ LL9/PG/2020 atas pembiayaan oleh Direktorat Riset dan Pengabdian Masyarakat Deputi Bidang Penguatan Riset dan Pengembangan Kementrian
Riset dan Teknologi/Badan Riset dan Inovasi Nasional.

\section{Daftar Pustaka}

1. Hastuti B, Tulus N. Sintesis kitosan dari cangkang Kerang Bulu (Anadara inflata) sebagai adsorben ion $\mathrm{Cu}^{2+}$. Prosiding Seminar Nasional Kimia dan Pendidikan Kimia VII. Surakarta: P.MIPA FKIP UNS; 2015.

2. Sudarmawan WS, Suprijanto J, Riniatsih I. Abu Cangkang Kerang Anadara granosa, Linnaeus 1758 (Bivalvia: Arcidae) sebagai Adsorben Logam Berat dalam Air Laut. Journal of Marine Research. 2020;9(3):237-44.

3. Mulyaningsih MFS, Rudi F, Ahmad S, Nofrin S. Isolasi Kitosan Dari Kulit Udang. Prosiding SENATEK Fakultas Teknik, Universitas Muhammadiyah Purwokerto; 2015:66-9.

4. Riski R, Sami FJ. Formulasi krim anti jerawat dari nanopartikel kitosan Cangkang Udang Windu (Penaeusmonodon). Jurnal Farmasi FIK UINAM. 2015;3(4):153-61.

5. Singh $S$, Khare M, Patidar RK, Bagde S, Sahare KN, Dwivedi D, Singh V. Antibacterial Activities Against Pyogenic Pathogens. International Journal of Pharmaceutical Sciences and Research. 2013;4(8):2974-9.

6. Qureshi AH, Rafi S, Qureshi SM, Ali AM. The current susceptibility patterns of methicillin resistant Staphylococcus aureus to conventional anti Staphylococcus antimicrobials at Rawalpindi. PakJ Med Sci. 2004;20(4):361-4

7. Khusnan K, Prihtiyantoro W, Hartatik H, Slipranata M. Karakterisasi Faktor-faktor Virulensi Staphylococcus aureus Asal Susu Kambing Peranakan Ettawa secara Fenotip dan Genotip. Jurnal Sain Veteriner. 2016;34(1):13043.

8. Sanjaya I, Yuanita L. Adsorpsi Pb (II) oleh Kitosan Hasil Isolasi Kitin Cangkang Kepiting Bakau (Scylla sp). Jurnal Ilmu Dasar. 2007;8(1):30-6. 
9. Bahri S, Rahim EA, Syarifuddin S. Derajat deasetilasi kitosan dari cangkang kerang darah dengan penambahan naoh secara bertahap. KOVALEN: Jurnal Riset Kimia. 2015;1(1):36-42.

10. Suherman S, Latif M, Dewi ST. Potensi Kitosan Kulit Udang Vannemei (Litopenaeus vannamei) Sebagai Antibakteri Terhadap Staphylococccus epidermidis, Pseudomonas aeruginosa, Propionibacterium agnes, dan Escherichia coli dengan Metode Difusi Cakram Kertas. Media Farmasi. 2018;14(1):132-43.

11. Killay A. Kitosan Sebagai Anti Bakteri pada Bahan Pangan yang Aman dan Tidak Berbahaya. Prosiding FMIPA Universitas Pattimura; 2013:200-5.

12. Agustina S, Swantara IM, Suartha IN. Isolasi kitin, karakterisasi, dan sintesis kitosan dari kulit udang. Jurnal Kimia. 2015;9(2):271-8.

13. Mohadi R, Hidayati N, Melany NR. Preparasi dan Karakterisasi Kompleks Kitosan HidrogelTembaga (II). Molekul. 2007;2(1):35-43.

14. Susilowati, Evelina S, Sutarno. Pembuatan Bioadsorben IIC-Zn Dari Kulit Udang Asal Teluk Bintuni. Mekanika. 2015;14(1):1-7.

15. Sarwono R. Pemanfaatan Kitin/Kitosan Sebagai
Bahan Antimikroba. Jurnal Kimia Terapan Indonesia. 2010;12(1):32-8.

16. Sulistiyoningrum RS, Suprijanto J, Sabdono A. Aktivitas anti bakteri kitosan dari cangkang kerang simping pada kondisi lingkungan yang berbeda: kajian pemanfaatan limbah kerang simping (Amusium sp.). Journal of marine research. 2013;2(4):111-7.

17. Apsari AT, Fitriasti D. Studi Kinetika Penjerapan Ion Khromium dan Ion Tembaga menggunakan Kitosan Produk dari Cangkang Kepiting. Skripsi Jurusan Teknik Kimia Fakultas Teknik Universitas Universitas Diponegoro. Semarang; 2010.

18. Sugita P, Wukirsari T, Sjahriza A, Wahyono D. Kitosan: sumber biomaterial masa depan. Bogor: IPB press; 2009.

19. Liu N, Chen XG, Park HJ, Liu CG, Liu CS, Meng XH, Yu LJ. Effect of MW and concentration of chitosan on antibacterial activity of Escherichia coli. Carbohydrate polymers. 2006;64(1):60-5.

20. Theron MM, Lues JFR. Organic Acids and Food Preservation. United States: CRC Press; 2010.

21. Bjornsdottir K, Breidt F, McFeeters RF. Protective effects of organic acids on survival of Escherichia coli 0157: $\mathrm{H7}$ in acidic environments. Applied and environmental microbiology. 2006;72(1):660-4. 